\title{
Assessment: Botulinum neurotoxin for the treatment of spasticity (an evidence-based review)
}

\author{
Report of the Therapeutics and Technology Assessment \\ Subcommittee of the American Academy of Neurology \\ [1]
}

D.M. Simpson, MD

J.-M. Gracies, MD, $\mathrm{PhD}$

H.K. Graham, MD

J.M. Miyasaki, MD, MEd

M. Naumann, MD

B. Russman, MD

L.L. Simpson, $\mathrm{PhD}$

Y. So, MD, PhD

Address correspondence and reprint requests to the

American Academy of Neurology, 1080 Montreal

Ave., St. Paul, MN 55116 guidelines@aan.com

Supplemental data at www.neurology.org

See pages 1699 and 1707

\section{ABSTRACT}

Objective: To perform an evidence-based review of the safety and efficacy of botulinum neurotoxin (BoNT) in the treatment of adult and childhood spasticity.

Methods: A literature search was performed including MEDLINE and Current Contents for therapeutic articles relevant to BoNT and spasticity. Authors reviewed, abstracted, and classified articles based on American Academy of Neurology criteria (Class I-IV).

Results: The highest quality literature available for the respective indications was as follows: adult spasticity (14 Class I studies); spastic equinus and adductor spasticity in pediatric cerebral palsy (six Class I studies).

Recommendations: Botulinum neurotoxin should be offered as a treatment option for the treatment of spasticity in adults and children (Level A). Neurology 2008;70:1691-1698

\section{GLOSSARY}

BoNT = botulinum neurotoxin; $\mathbf{C P}=$ cerebral palsy; FDA = Food and Drug Administration; SNAP = synaptosomal-associated protein; VAMP = vesicle-associated membrane protein .

INTRODUCTION Pharmacology and immunology of botulinum toxin. Botulinum neurotoxin $(\mathrm{BoNT})$ is a microbial protein that exists in seven serotypes, designated A through G. Although the individual serotypes are immunologically distinct, all members of the group possess similar subunit structures, act on the same target organs, and produce similar functional outcomes. ${ }^{1,2}$ Each molecule is typically released from bacteria as part of a noncovalent complex with other proteins. These auxiliary proteins do not play a role in the therapeutic actions of the toxin, but they may be involved in its undesirable effects.

BoNT is an enzyme that acts in the cytosol of nerve endings to cleave three polypeptides that govern exocytosis. Serotypes A and E cleave synaptosomal-associated protein (SNAP)-25, serotypes $\mathrm{B}, \mathrm{D}, \mathrm{F}$, and $\mathrm{G}$ cleave vesicle-associated membrane protein (VAMP), and serotype C cleaves both syntaxin and SNAP-25. ${ }^{3,4}$ The ability of BoNT to block acetylcholine release at neuromuscular junctions accounts for its therapeutic action to relieve dystonia, spasticity, and related disorders. The toxin has additional therapeutic benefits, not necessarily related to neuromuscular transmission. These include 1) blockade of acetylcholine release at autonomic nerve endings and 2) blockade of transmitter release at peripheral nerve endings that use mediators other than acetylcholine. In addition to peripheral effects of BoNT, indirect effects on the spinal cord and brain that result from changes in the normal balance of efferent and afferent signals may also occur. Both the direct and indirect actions of the toxin are largely or completely reversible.

Undesirable effects associated with administration of BoNT fall into three broad categories. First, diffusion of the toxin from the intended

From the Department of Neurology (D.M.S.), Mount Sinai Medical Center, New York, NY; Department of Rehabilitation Medicine (J.M.G.), CHU Henri Mondor, Créteil, France; Department of Orthopaedic Surgery (H.K.G.), Royal Children's Hospital, Victoria, Australia; Toronto Western Hospital (J.M.M.), Ontario, Canada; Department of Neurology (M.N.), Klinikum Augsburg, Germany; Shriners Hospital for Children (B.R.), Portland, OR; Jefferson Medical College (L.L.S.), Philadelphia, PA; and Stanford University (Y.S.), CA.

Approved by the Therapeutics and Technology Assessment Subcommittee on March 31, 2007; by the Practice Committee on July 12, 2007; and by the AAN Board of Directors on January 30, 2008.

The Mission Statement, Conflict of Interest Statement, Subcommittee and Panel members, AAN classification of evidence, and Classification of recommendations are available as supplemental data on the Neurology ${ }^{\circledR}$ Web site at www.neurology.org.

Endorsed by the American Academy of Physical Medicine and Rehabilitation on March 14, 2008.

Disclosure: Author disclosures are provided at the end of the article. 
sites of action can lead to unwanted inhibition of transmission at neighboring nerve endings. Second, sustained blockade of transmission can produce effects similar to anatomic denervation, including muscle atrophy. The third undesirable effect is immunoresistance to BoNT. ${ }^{5}$ Resistance results from the development of circulating antibodies that bind to the heavy chain and prevent its association with nerve membranes, thus preventing internalization of the enzymatically active light chain. Auxiliary proteins in the toxin complex could act as adjuvants to stimulate the immune response to the toxin in keeping with the lower incidence of immunoresistance associated with the decreased proportion of nontoxin protein in clinical preparations. ${ }^{6}$

As of January 2008, two BoNT serotypes (A and B) are Food and Drug Administration (FDA) approved for clinical use in the United States. Botox ${ }^{\circledR}$ is approved for the treatment of strabismus, blepharospasm, cervical dystonia, axillary hyperhidrosis, and glabellar lines, and Myobloc ${ }^{\circledR}$ is approved for cervical dystonia. There are broader regulatory approvals in Europe, including focal adult spasticity. Other serotypes of BoNT are being evaluated in clinical trials. BoNT-A is marketed as Botox ${ }^{\circledR}$ (Allergan, Inc.), Dysport ${ }^{\circledR}$ (Ipsen Limited), a Chinese formulation, Hengli (Lanzhou Institute of Biologic Products), and Xeomin $^{\circledR}$ (Merz Pharmaceuticals), while BoNT-B is marketed as Myobloc ${ }^{\circledR}$ (Solstice Neurosciences, Inc.), also called Neurobloc ${ }^{\circledR}$ in some countries. Within BoNT-A brands, there are differences in potency among Botox ${ }^{\circledR}$, Xeomin ${ }^{\circledR}$, and Dysport ${ }^{\circledR}$ that require differences in dosages.

Controversy surrounds the definition of BoNT potency. The standard unit of BoNT potency is derived from the mouse lethality assay, in which 1 mouse unit is defined as the amount of BoNT that kills $50 \%$ of mice when injected intraperitoneally (i.e., LD50). However, the assay methodology varies among manufacturers, making dose comparison difficult. Furthermore, it is difficult to extrapolate animal data to potency in humans, given the relative lack of head-to-head studies of different BoNT preparations. With these limitations, cross-study comparisons have resulted in relative dose equivalents of Botox ${ }^{\circledR}$ : Dysport ${ }^{\circledR}$ : Myobloc $^{\circledR}$ of approximately 1:3-4:50-100. However, given the high range of intra- and interpatient variability, doses must be established for each BoNT preparation for individual patients. ${ }^{7}$ Both basic science and clinical studies indicate that BoNT-A has a longer duration of action than BoNT-B. ${ }^{8}$
DESCRIPTION OF THE ANALYTICAL PROCESS The literature search used MEDLINE and Current Contents for relevant, fully published, peer-reviewed articles up to April 2007 and was supplemented through manual searches by panel members. The search terms used were botulinum toxin and movement disorders, dystonia, tics, tremors, hemifacial spasm, blepharospasm, cerebral palsy, spasticity, autonomic, Frey's syndrome, sweating, hyperhydrosis, drooling, headache, back pain, pain, laryngeal disorders, dysphonia, and urologic disorders. The following criteria were used: 1) relevant to the clinical questions of efficacy, safety, tolerability, or mode of use; 2) limited to human subjects; 3) limited to therapeutic studies. Abstracts, reviews, and metaanalyses were excluded.

The panel was comprised of specialists with experience in the therapeutic use of BoNT for the indications under consideration or with expertise in guideline methodology. Each article was reviewed by at least two panelists who did not participate in the trial reported. The articles were classified as Class I through IV using the AAN guideline process (see AAN classification of evidence for therapeutic intervention on the Neurology ${ }^{\circledR}$ Web site at www.neurology.org.). Disagreements on article classification were resolved by discussion and consensus.

Since the different preparations of BoNT have different potencies and durations of action, and there are insufficient head-to-head comparison data to compare their clinical effects, the serotype and brand of BoNT used in specific studies are provided in the evidence tables, but the text distinguishes their effects only when the data are sufficient to do so, or when referring to specific dosages. The current article reviews the use of BoNT for the following indications: adult spasticity and spasticity in pediatric cerebral palsy. Two companion articles review the use of BoNT for other conditions: one on headache, back pain, autonomic, and urologic disorders, ${ }^{9}$ and another on selected movement disorders, including blepharospasm, hemifacial spasm, cervical dystonia, focal limb dystonia, laryngeal dystonia, and tics and tremor. ${ }^{10}$ While brief mention is made of other treatments for the covered indications, discussion of detailed evidence supporting their efficacy is beyond the scope of this article.

ANALYSIS OF EVIDENCE Spasticity in adults. Spasticity results from diverse etiologies including stroke, trauma, multiple sclerosis, and neoplasm involving the CNS. Reduction in function is re- 
lated to at least three factors: muscle weakness, soft tissue contracture, and muscle overactivity. BoNT in a spastic muscle should, in theory, affect each of these mechanisms of impairment as follows: 1) by reducing spastic co-contraction (inappropriate antagonistic co-activation during volitional command on an agonist); 2) by decreasing spastic dystonia (stretch-sensitive tonic muscle contraction, in the absence of volitional command) of the injected muscle; 3 ) by contributing to ease the stretch and lengthening of the injected muscle; and 4) by helping to increase antagonist torque.

Treatment options for spastic paresis include physical and occupational therapy, bracing/splinting, tizanidine, benzodiazepines, oral or intrathecal baclofen, tendon release, and rhizotomy. Most clinical trials of BoNT in the treatment of adult spasticity have emphasized changes in resistance to passive movement (i.e., muscle tone). While active (i.e., voluntary) functional improvement with BoNT is reported in case series and frequently observed in clinical practice, there is no consensus on appropriate outcome measures for active function. BoNT has been approved for adult and childhood spasticity by regulatory agencies in many European countries, but has not yet been approved for these indications in the United States by the FDA.

Upper extremity spasticity. There are 11 Class I efficacy trials in adult upper extremity spasticity, with 10 utilizing BoNT-A and one BoNT-B (table e- 1 on the Neurology ${ }^{\mathbb{R}}$ Web site at www.neurology. org). ${ }^{11-21}$ All but one used measurements of tone as the primary outcome measure. All demonstrated that BoNT is safe and reduced tone in a dosedependent manner. ${ }^{14,15,17,20,22}$ Global satisfaction scores reported by subjects, family members, or clinicians showed benefits of BoNT. Recent open label trials suggest that benefits continue to occur after repeated injections. ${ }^{23,24}$ However, resistance to passive movement has not been shown to correlate with active function, defined as activities that the subject can voluntarily perform with the spastic limb. Although no Class I studies of BoNT in the spastic upper limb focused on active functional gains as a primary outcome measure, functional assessment measures have been used as secondary outcome measures.

Class I studies incorporating subjective assessments of daily function by the patient or caregiver have shown functional improvement following BoNT injection in the spastic upper limb. ${ }^{12,14,15,17}$ These reports usually emphasize passive func- tion, such as tasks involving the nonaffected hand or dressing or hygiene performed by the caregiver. One Class I study found that BoNT produced significant improvement in the Disability Assessment Score, which combines reports of passive and active function. ${ }^{18}$ In this scale, the subject and the site investigator chose a target area of outcome assessment of personal hygiene, dressing, pain, or limb position and rated the area using a four-point scale ranging from no to severe disability. Although direct assessments of functional tasks by a clinician have the advantage of greater objectivity and permit selective testing of active function, ${ }^{14,15,17,21}$ significant gains were reported in only one Class I study measuring active functional testing in adult upper limb spasticity. ${ }^{21}$

Lower extremity spasticity. Three trials fulfilled criteria for Class I evidence ${ }^{17,25,26}$ (table e-2). Most studies focused on reduction in muscle tone with demonstrated efficacy, but only few measured changes in gait, particularly velocity. One placebo-controlled crossover protocol ${ }^{22}$ reported a nonsignificant $17 \%$ increase in walking speed after BoNT injection into calf muscles in spastic hemiparesis. Class I placebo-controlled studies have so far failed to demonstrate gains in walking speed. ${ }^{17,21}$ Reports suggest that protocols of low frequency electrical stimulation of injected muscles after injection enhance the blocking effect of BoNT, ${ }^{27}$ and in particular improve the benefit on walking speed after calf muscle injection. ${ }^{28}$ In a double-blind, placebo-controlled, crossover study, patients with multiple sclerosis and severe spasticity of thigh adductors receiving BoNT-A (400 U) in hip adductor muscles had functional gain, specifically easier nursing care, and better comfort when sitting in a wheelchair. ${ }^{29}$

Most studies of BoNT in limb spasticity used electrophysiologic techniques to optimize muscle localization for injection, analogous to focal limb dystonia. The most common approaches involve electrical stimulation or EMG. While these techniques are intuitively attractive, there is a lack of controlled or comparative studies in spasticity proving their effectiveness over other injection techniques, such as needle localization with anatomic landmarks. Recommended doses of BoNT injection into specific muscles have been derived predominantly from expert consensus rather than dose-response studies.

Conclusions. BoNT is established as effective in the treatment of adult spasticity in the upper and lower limb in reducing muscle tone and improving passive function (14 Class I studies). While 


\begin{tabular}{|c|c|c|c|c|c|c|c|}
\hline Table & mary table & r botulin & $u m$ toxin in the treatment & f spasticity & & & \\
\hline Disorder & Class & $\begin{array}{l}\text { No. of } \\
\text { subjects }\end{array}$ & Outcome measures & Adverse events & Conclusions & Recommendations* & Limitations \\
\hline \multirow[t]{2}{*}{ Adult spasticity } & 14 Class I & 906 & $\begin{array}{l}\text { Tone (Ashworth), passive } \\
\text { fx: range of motion, } \\
\text { cleaning, hygiene, pain }\end{array}$ & $\begin{array}{l}\text { Focal weakness, } \\
\text { pain }\end{array}$ & $\begin{array}{l}\text { Established safe } \\
\text { and effective }\end{array}$ & A & $\begin{array}{l}\text { Methodologic challenges in } \\
\text { study design }\end{array}$ \\
\hline & & & $\begin{array}{l}\text { Active fx: Goal Attainment } \\
\text { Scale, Frenchay; global } \\
\text { disability (MD/pt) }\end{array}$ & & $\begin{array}{l}\text { Probably } \\
\text { effective }\end{array}$ & B & $\begin{array}{l}\text { Limited outcome measures } \\
\text { to demonstrate efficacy in } \\
\text { active functional gains }\end{array}$ \\
\hline $\begin{array}{l}\text { Childhood } \\
\text { spasticity in } \\
\text { cerebral palsy }\end{array}$ & 6 Class 1 & 376 & $\begin{array}{l}\text { Tone (Ashworth), passive } \\
\text { fx: range of motion, active } \\
\text { fx: gait/video/kinematic } \\
\text { analysis; global disability } \\
\text { (MD/pt) }\end{array}$ & $\begin{array}{l}\text { Pain, weakness, } \\
\text { falls, incontinence, } \\
\text { dysphagia }\end{array}$ & $\begin{array}{l}\text { Established safe } \\
\text { and effective }\end{array}$ & $A$ & $\begin{array}{l}\text { Best evidence for equinus } \\
\text { varus }\end{array}$ \\
\hline
\end{tabular}

${ }^{*}$ Classification of recommendations is available on the Neurology ${ }^{\circledR}$ Web site at www.neurology.org.

$A=$ should be offered; $B=$ should be considered; $C=$ may be considered; $f x=$ function; $M D=$ physician; $p t=p a t i e n t$.

relatively few studies examined active function, recent data suggest that BoNT is probably effective in improving active function (one Class I study). There are inadequate data to determine if electrical stimulation or EMG techniques for optimal muscle localization improves outcome.

\section{Recommendations}

- BoNT should be offered as a treatment option to reduce muscle tone and improve passive function in adults with spasticity (Level A), and should be considered to improve active function (Level B).

- There is insufficient evidence to recommend an optimum technique for muscle localization at the time of injection (Level U).

Clinical context. There are no controlled studies comparing BoNT to other treatment modalities for spasticity. There is also a need to confirm efficacy for active function in controlled trials. This will require solying methodologic challenges of study design, including enrollment criteria that provide more homogeneous etiologies and degrees of severity of spastic paresis, and outcome measures adequate to demonstrate active motor function.

Spasticity due to cerebral palsy in children. Cerebral palsy $(\mathrm{CP})$ is a disorder of movement and posture as a result of a CNS abnormality. Muscle hypertonia, coupled with growth of a child, can lead to fixed contractures, torsional deformities of long bones, and joint instability, which further impair the child's motor performance. Treatment options for childhood CP include physical and occupational therapy, splinting/casting, and surgical approaches, such as tendon release and selective dorsal rhizotomy. Early studies suggested that BoNT injections could be used as an alternative treatment for an equinus varus deformity and obviate the need for surgery prior to gait maturity. Since that time, over 80 articles have been published discussing the use of BoNT-A in the management of CP.

Spastic equinus. Four Class I studies ${ }^{30-33}$ of BoNT injection into the gastrocnemius improved gait over 1 to 3 months (table e-3). The optimal dosage for different body weight and age range has not been established. One Class $\mathrm{I}^{32}$ and two Class II studies $^{34,35}$ evaluated the efficacy of different doses. In all three studies, the highest dose was most effective (24 or $30 \mathrm{U} / \mathrm{Kg}$ Dysport ${ }^{\circledR}$, or $200 \mathrm{U}$ Botox $^{\circledR}$ regardless of weight). Several randomized single-blind studies compared the effect of ankle casting to BoNT injections in a small number of children. ${ }^{36-41}$ Casting did not provide additional benefit (table e-3).

Hamstrings. Two small open-label studies (Class IV) found modest improvement in either gait kinematics or hamstring length with BoNT injection into the hamstrings. ${ }^{42,43}$

Adductor spasticity. One Class $\mathrm{I}^{44}$ study using BoNT injection into the adductors and medial hamstrings showed an average improvement in knee-to-knee distance of about $9 \mathrm{~cm}(p<0.002)$ and decrease in adductor spasticity on modified Ashworth scale of 2 ( $p<0.001)$. Another Class I study ${ }^{45}$ evaluated the need for postoperative pain control in children undergoing adductor muscle lengthening. There was a $74 \%$ reduction in postoperative pain $(p<0.003)$ and $50 \%$ less analgesic use $(p<0.005)$ when comparing BoNT-treated children to the placebo group.

Upper extremity spasticity. Goals for injection of the upper limb include the relief of spastic posturing and improvement in upper limb function. Two small Class II studies and one Class III study ${ }^{46-48}$ addressing the use of BoNT in the upper extremity described modest improvement in tone and range of movements, without demonstration of significant functional gains. 
Conclusions. BoNT injection of the gastrocnemiussoleus muscles is established as effective in the treatment of spastic equinus in patients with CP (four Class I studies). There is insufficient evidence to support or refute the benefit of additional casting to BoNT injection of the gastrocnemius-soleus muscles (inconsistent Class II and III studies) and the injection of BoNT into the hamstrings (only Class IV studies). In patients with adductor spasticity, BoNT injection is probably effective in improving adductor spasticity and range of motion (one Class I study), as well as postoperative pain in children undergoing adductor muscle lengthening surgery (one Class I study). In patients with upper extremity symptoms, BoNT injection is probably effective in improving spasticity and range of motion (two Class II studies and one Class III study).

\section{Recommendations}

- BoNT injection of the calf muscles should be offered as a treatment option for equinus varus deformity in children with cerebral palsy (Level A).

- BoNT injection should be considered as a treatment option for treatment of adductor spasticity and for pain control in children undergoing adductor-lengthening surgery (Level B).

- BoNT injection should be considered as a treatment option in children with upper extremity spasticity (Level B).

Clinical context. As in adult spasticity, there is lack of consensus on what constitutes meaningful functional gain following treatment for spasticity. While many clinicians, patients, and caregivers find the results of BoNT treatment for spasticity gratifying, the FDA has not approved BoNT for the treatment of spasticity in children.

Summary. The evidence supporting the use of BoNT in adult and childhood spasticity is summarized in the table.

\section{RECOMMENDATIONS FOR FUTURE RE- SEARCH}

- BoNT is now standard clinical practice for the treatment of many disorders of excess motor activity, including numerous forms of dystonia and spasticity. However, treatment response varies widely, within and among indications. Future studies should investigate factors that predict which patient subgroups have optimal response.

- Most patients would prefer not to have injections as frequently as currently required. Future directions will likely involve the development of other toxins, including those that are less costly, more accessible to those in need, with a longer duration of action, and with delivery approaches other than injection.

- A major limitation in published clinical trials of BoNT is the lack of standardized rating tools for many clinical indications (e.g., spasticity, focal hand dystonia). Furthermore, there is often disagreement among investigators, clinicians, patients, family members, and regulatory agencies as to what constitutes functional improvement. Future studies would benefit from the development of validated scales applicable across the spectrum of tasks eliciting the abnormal movements and sensitive to changes with focal treatment such as BoNT.

- Further studies on injection methodology including the use of EMG guidance, ultrasonography, and electrical stimulation are needed to optimize treatment technique.

- Many trials in the use of BoNT have used rigid injection protocols with insufficient attention to the capacity for individualized choice of muscles and doses. Study designs that leave the choice of target muscles and doses to the investigators' discretion are more likely to reflect clinical practice and may affect reported efficacy.

- More research is needed in the choice of muscles used in BoNT injection. For spasticity, selection might be based on qualitative assessments of overactivity at rest and during attempts at active motion, as opposed to relying on a quantitative tone score that may not reflect disability during attempts at active movements.

- More research is needed to determine the optimal dose of BoNT for individual muscles, and the choice of the number and location of injection sites.

- More studies are needed to assess the safety and efficacy of repeated and long-term injections of BoNT, and to address the risk of development of secondary resistance to BoNT due to antibody formation.

- In children with cerebral palsy, controlled studies are needed to study the long-term effect of BoNT injections, especially in relation to the growth and maturity of the children and the necessity and timing of orthopedic surgery. Much work remains to be done to determine whether BoNT injection is a minor supporting intervention for children with cerebral palsy or a mainstream 
standard therapy for the majority of children. For example, short- and long-term studies comparing the outcome of patients who receive BoNT therapy as part of the treatment program with the outcome of patients in those programs where BoNT is not part of the treatment regimen would be helpful.

- Further studies, including comparative head-to-head trials, are needed to establish whether one serotype or brand of BoNT is more effective than another, and to determine the dosing equivalency and relative antigenicity between serotypes and brands. It is not clear how such studies will be funded, which will likely require partnership among academic investigators, governmental agencies, and the pharmaceutical industry.

DISCLAIMER This statement is provided as an educational service of the American Academy of Neurology. It is based on an assessment of current scientific and clinical information. It is not intended to include all possible proper methods of care for a particular neurologic problem or all legitimate criteria for choosing to use a specific procedure. Neither is it intended to exclude any reasonable alternative methodologies. The AAN recognizes that specific patient care decisions are the prerogative of the patient and the physician caring for the patient, based on all of the circumstances involved. The clinical context section is made available in order to place the evidencebased guideline(s) into perspective with current practice habits and challenges. No formal practice recommendations should be inferred.

\section{ACKNOWLEDGMENT}

The authors thank Dr. Mitchell Brin for his contributions in the early phases of this project.

\section{DISCLOSURE}

The authors report the following conflicts: Dr. Simpson has received speaker honoraria and research support from Allergan, Merz, and Solstice, Inc., and performs botulinum toxin injections. Dr. Gracies has received speaker honoraria and research support from Allergan, Merz, and Solstice, Inc. Dr. Graham has received speaker honoraria and research support from Allergan and performs botulinum toxin injections. Dr. Miyasaki has received research support from Boehringer Ingelheim, Huntington Study Group, NIH, Solvay, Solstice, and Teva. Dr. Naumann has received speaker honoraria from Ipsen and Allergan and performs botulinum toxin injections. Dr. Russman has received research support from Allergan and performs botulinum toxin injections. Dr. L. Simpson has received research support from Allergan. Dr.
So holds financial interest in Satoris Inc., and has received research support from NIH, Pfizer, Inc., and NeurogesX, Inc.

Received December 6, 2007. Accepted in final form January 30, 2008

\section{REFERENCES}

1. Lacy DB, Stevens RC. Sequence homology and structural analysis of the clostridial neurotoxins. J Mol Biol 1999;291:1091-1104.

2. Johnson EA, Bradshaw M. Clostridium botulinum and its neurotoxins: a metabolic and cellular perspective. Toxicon 2001;39:1703-1722.

3. Simpson LL. Identification of the major steps in botulinum toxin action. Annu Rev Pharmacol Toxicol 2004; 44:167-193.

4. Humeau Y, Doussau F, Grant NJ, Poulain B. How botulinum and tetanus neurotoxins block neurotransmitter release. Biochimie 2000;82:427-446.

5. Dressler D, Hallett M. Immunological aspects of Botox, Dysport and Myobloc/NeuroBloc. Eur J Neurol 2006;13 Suppl 1:11-15.

6. Jankovic J, Vuong KD, Ahsan J. Comparison of efficacy and immunogenicity of original versus current botulinum toxin in cervical dystonia. Neurology 2003; 60:1186-1188.

Guyer BM. Some unresolved issues with botulinum toxin. J Neurol 2001;248 suppl 1:11-13.

8. Comella CL, Jankovic J, Shannon KM, et al. Comparison of botulinum toxin serotypes A and B for the treatment of cervical dystonia. Neurology 2005;65:14231429.

9. Naumann M, So Y, Argoff CE, et al. Assessment: Botulinum neurotoxin in the treatment of autonomic disorders and pain (an evidence-based review): Report of the Therapeutics and Technology Assessment Subcommittee of the American Academy of Neurology. Neurology 2008;70:1699-1706.

10. Simpson DM, Blitzer A, Brashear A, et al. Assessment: Botulinum neurotoxin for the treatment of movement disorders (an evidence-based review): Report of the Therapeutics and Technology Assessment Subcommittee of the American Academy of Neurology. Neurology 2008;70:1691-1698.

11. Hesse S, Reiter F, Konrad M, Jahnke MT. Botulinum toxin type A and short-term electrical stimulation in the treatment of upper limb flexor spasticity after stroke: a randomized, double-blind, placebocontrolled trial. Clin Rehabil 1998;12:381-388.

12. Smith SJ, Ellis E, White S, Moore AP. A double-blind placebo-controlled study of botulinum toxin in upper limb spasticity after stroke or head injury. Clin Rehabil 2000;14:5-13.

13. Bhakta BB, Cozens JA, Chamberlain MA, Bamford JM. Impact of botulinum toxin type A on disability and carer burden due to arm spasticity after stroke: a randomised double blind placebo controlled trial [erratum appears in 2001;70:821]. J Neurol Neurosurg Psychiatry 2000;69:217-221.

14. Bakheit AM, Pittock S, Moore AP, et al. A randomized, double-blind, placebo-controlled study of the efficacy and safety of botulinum toxin type A in upper limb spasticity in patients with stroke. Eur J Neurol 2001;8: 559-565. 
15. Bakheit AM, Thilmann AF, Ward AB, et al. A randomized, double-blind, placebo-controlled, dose-ranging study to compare the efficacy and safety of three doses of botulinum toxin type A (Dysport) with placebo in upper limb spasticity after stroke. Stroke 2000;31:2402-2406.

16. Simpson DM, Alexander DN, O'Brien CF, et al. Botulinum toxin type $\mathrm{A}$ in the treatment of upper extremity spasticity: a randomized, double-blind, placebocontrolled trial. Neurology 1996;46:1306-1310.

17. Richardson D, Sheean G, Werring D, et al. Evaluating the role of botulinum toxin in the management of focal hypertonia in adults. J Neurol Neurosurg Psychiatry 2000;69:499-506.

18. Brashear A, Gordon MF, Elovic E, et al. Intramuscular injection of botulinum toxin for the treatment of wrist and finger spasticity after a stroke. N Engl J Med 2002; 347:395-400.

19. Childers MK, Brashear A, Jozefczyk P, et al. Dosedependent response to intramuscular botulinum toxin type A for upper-limb spasticity in patients after a stroke. Arch Phys Med Rehabil 2004;85:1063-1069.

20. Brashear A, McAfee AL, Kuhn ER, Fyffe J. Botulinum toxin type B in upper-limb poststroke spasticity: a double-blind, placebo-controlled trial. Arch Phys Med Rehabil 2004;85:705-709.

21. Suputtitada A, Suwanwela NC. The lowest effective dose of botulinum A toxin in adult patients with upper limb spasticity. Disabil Rehabil 2005;27:176-184.

22. Burbaud P, Wiart L, Dubos JL, et al. A randomised, double blind, placebo controlled trial of botulinum toxin in the treatment of spastic foot in hemiparetic patients. J Neurol Neurosurg Psychiatry 1996;61:265-269.

23. Gordon MF, Brashear A, Elovic E, et al. Repeated dosing of botulinum toxin type A for upper limb spasticity following stroke. Neurology 2004;63:1971-1973.

24. Bakheit AM, Fedorova NV, Skoromets AA, Timerbaeva SL, Bhakta BB, Coxon L. The beneficial antispasticity effect of botulinum toxin type $\mathrm{A}$ is maintained after repeated treatment cycles. J Neurol Neurosurg Psychiatry 2004;75:1558-1561.

25. Hyman N, Barnes M, Bhakta B, et al. Botulinum toxin (Dysport) treatment of hip adductor spasticity in multiple sclerosis: a prospective, randomised, double blind, placebo controlled, dose ranging study. J Neurol Neurosurg Psychiatry 2000;68:707-712.

26. Pittock SJ, Moore AP, Hardiman O, et al. A doubleblind randomised placebo-controlled evaluation of three doses of botulinum toxin type A (Dysport) in the treatment of spastic equinovarus deformity after stroke. Cerebrovasc Dis 2003;15:289-300.

27. Frasson E, Priori A, Ruzzante B, Didone G, Bertolasi L. Nerve stimulation boosts botulinum toxin action in spasticity. Mov Disord 2005;20:624-629.

28. Johnson CA, Burridge JH, Strike PW, Wood DE, Swain ID. The effect of combined use of botulinum toxin type A and functional electric stimulation in the treatment of spastic drop foot after stroke: a preliminary investigation. Arch Phys Med Rehabil 2004;85:902-909.

29. Snow BJ, Tsui JK, Bhatt MH, Varelas M, Hashimoto SA, Calne DB. Treatment of spasticity with botulinum toxin: a double-blind study. Ann Neurol 1990;28:512-515.

30. Sutherland DH, Kaufman KR, Wyatt MP, Chambers HG, Mubarak SJ. Double-blind study of botulinum A toxin injections into the gastrocnemius muscle in patients with cerebral palsy. Gait Posture 1999;10:1-9.

31. Ubhi T, Bhakta BB, Ives HL, Allgar V, Roussounis SH. Randomised double blind placebo controlled trial of the effect of botulinum toxin on walking in cerebral palsy. Arch Dis Child 2000;83:481-487.

32. Baker R, Jasinski M, Maciag-Tymecka I, et al. Botulinum toxin treatment of spasticity in diplegic cerebral palsy: a randomized, double-blind, placebo-controlled, dose-ranging study. Dev Med Child Neurol 2002;44: 666-675.

33. Koman LA, Mooney 3rd JF, Smith BP, Walker F, Leon JM. Botulinum toxin type A neuromuscular blockade in the treatment of lower extremity spasticity in cerebral palsy: a randomized, double-blind, placebocontrolled trial. BOTOX Study Group. J Pediatr Orthop 2000;20:108-115.

34. Wissel J, Heinen F, Schenkel A, et al. Botulinum toxin $\mathrm{A}$ in the management of spastic gait disorders in children and young adults with cerebral palsy: a randomized, double-blind study of "high-dose" versus "lowdose" treatment. Neuropediatrics 1999;30:120-124.

35. Polak F, Morton R, Ward C, Wallace WA, Doderlein L, Siebel A. Double-blind comparison study of two doses of botulinum toxin A injected into calf muscles in children with hemiplegic cerebral palsy. Dev Med Child Neurol 2002;44:551-555.

36. Ackman JD, Russman BS, Thomas SS, et al. Comparing botulinum toxin A with casting for treatment of dynamic equinus in children with cerebral palsy. Dev Med Child Neurol 2005;47:620-627.

37. Corry IS, Cosgrove AP, Duffy CM, McNeill S, Taylor TC, Graham HK. Botulinum toxin A compared with stretching casts in the treatment of spastic equinus: a randomised prospective trial. J Pediatr Orthop 1998; 18:304-311.

38. Desloovere K, Molenaers G, Jonkers I, et al. A randomized study of combined botulinum toxin type A and casting in the ambulant child with cerebral palsy using objective outcome measures. Eur J Neurol 2001;8 suppl 5:75-87.

39. Flett PJ, Stern LM, Waddy H, Connell TM, Seeger JD, Gibson SK. Botulinum toxin A versus fixed cast stretching for dynamic calf tightness in cerebral palsy. J Paediatr Child Health 1999;35:71-77.

40. Bottos M, Benedetti MG, Salucci P, Gasparroni V, Giannini S. Botulinum toxin with and without casting in ambulant children with spastic diplegia: a clinical and functional assessment. Dev Med Child Neurol 2003;45: 758-762.

41. Kay RM, Rethlefsen SA, Fern-Buneo A, Wren TA, Skaggs DL. Botulinum toxin as an adjunct to serial casting treatment in children with cerebral palsy. J Bone Joint Surg Am 2004;86-A:2377-2384.

42. Corry IS, Cosgrove AP, Duffy CM, Taylor TC, Graham HK. Botulinum toxin A in hamstring spasticity. Gait Posture 1999;10:206-210.

43. Thompson NS, Baker RJ, Cosgrove AP, Corry IS, Graham HK. Musculoskeletal modelling in determining the effect of botulinum toxin on the hamstrings of patients with crouch gait. Dev Med Child Neurol 1998; 40:622-625.

44. Mall V, Heinen F, Siebel A, et al. Treatment of adductor spasticity with BTX-A in children with CP: a ran- 
domized, double-blind, placebo-controlled study. Dev Med Child Neurol 2006;48:10-13.

45. Barwood S, Baillieu C, Boyd R, et al. Analgesic effects of botulinum toxin A: a randomized, placebo-controlled clinical trial. Dev Med Child Neurol 2000;42:116-121.

46. Corry IS, Cosgrove AP, Walsh EG, McClean D, Graham HK. Botulinum toxin A in the hemiplegic upper limb: a double-blind trial. Dev Med Child Neurol 1997; 39:185-193.
47. Fehlings D, Rang M, Glazier J, Steele C. An evaluation of botulinum-A toxin injections to improve upper extremity function in children with hemiplegic cerebral palsy. J Pediatr 2000;137:331-337.

48. Speth LA, Leffers P, Janssen-Potten YJ, Vles JS. Botulinum toxin A and upper limb functional skills in hemiparetic cerebral palsy: a randomized trial in children receiving intensive therapy. Dev Med Child Neurol 2005;47:468-473.

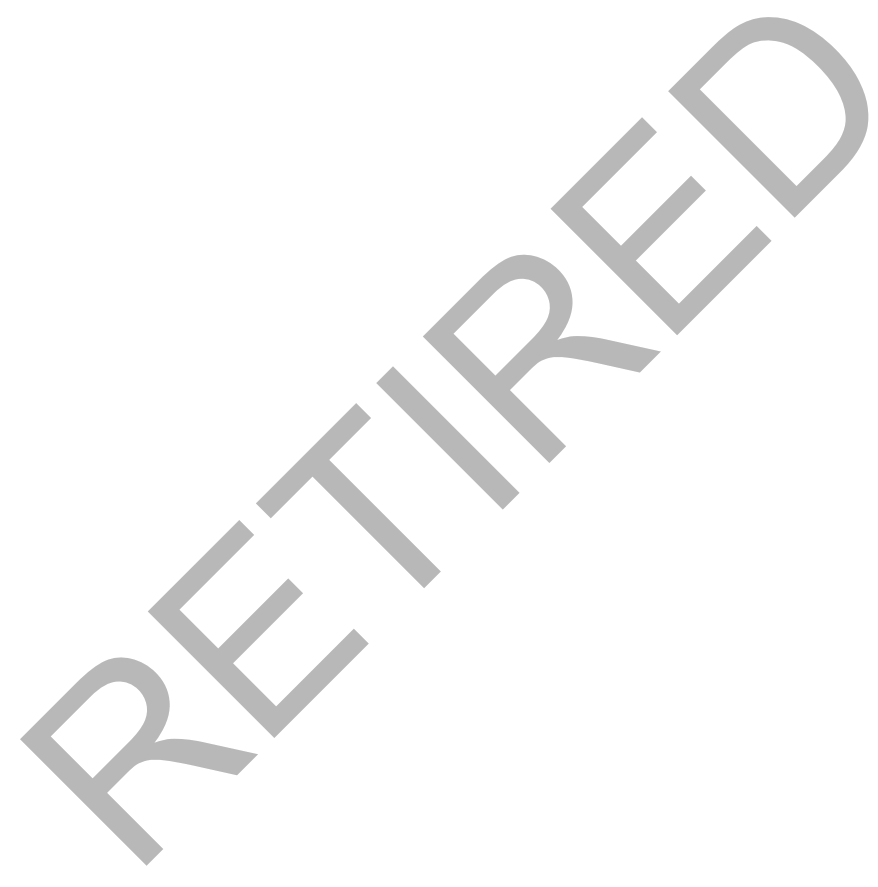




\section{Neurology}

\section{Assessment: Botulinum neurotoxin for the treatment of spasticity (an evidence-based review): [RETIRED]: Report of the Therapeutics and Technology Assessment Subcommittee of the American Academy of Neurology}

D. M. Simpson, J-M Gracies, H. K. Graham, et al. Neurology 2008;70;1691-1698

DOI 10.1212/01.wnl.0000311391.00944.c4

This information is current as of May 5, 2008

\section{Updated Information \& Services}

Supplementary Material

\section{References}

Citations

Subspecialty Collections

Permissions \& Licensing

Reprints including high resolution figures, can be found at: http://n.neurology.org/content/70/19/1691.full

Supplementary material can be found at: http://n.neurology.org/content/supp1/2009/11/06/70.19.1691.DC2 http://n.neurology.org/content/supp1/2008/05/29/70.19.1691.DC1

This article cites 48 articles, 13 of which you can access for free at: http://n.neurology.org/content/70/19/1691.full\#ref-list-1

This article has been cited by 18 HighWire-hosted articles: http://n.neurology.org/content/70/19/1691.full\#\#otherarticles

This article, along with others on similar topics, appears in the following collection(s):

\section{All Cerebrovascular disease/Stroke}

http://n.neurology.org/cgi/collection/all_cerebrovascular_disease_strok e

Information about reproducing this article in parts (figures,tables) or in its entirety can be found online at:

http://www.neurology.org/about/about_the_journal\#permissions

Information about ordering reprints can be found online:

http://n.neurology.org/subscribers/advertise

Neurology ${ }^{\circledR}$ is the official journal of the American Academy of Neurology. Published continuously since 1951, it is now a weekly with 48 issues per year. Copyright . All rights reserved. Print ISSN: 0028-3878. Online ISSN: 1526-632X.

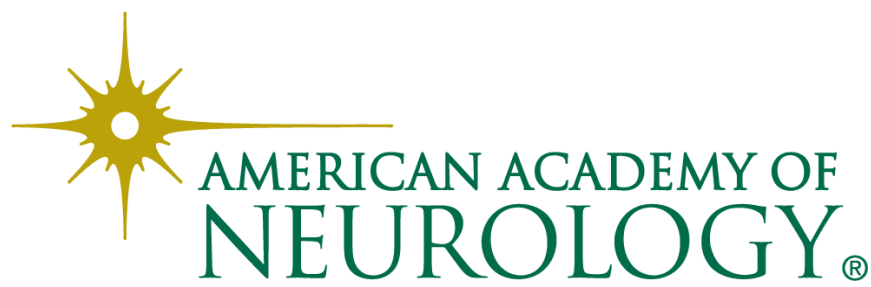

